Volume 5 Nomor 2, Agustus 2020, halaman 154-171

\title{
PROSES BERPIKIR KRITIS DAN KESALAHAN SISWA DALAM PEMECAHAN MASALAH MATEMATIKA DITINJAU DARI TIPE KEPRIBADIAN DOMINANCE-INFLUENCE
}

\author{
CRITICAL THINKING PROCESS AND STUDENT ERRORS IN \\ SOLUTION OF MATHEMATIC PROBLEMS VIEWED FROM TYPE \\ DOMINANCE-INFLUENCE PERSONALITY
}

\author{
Mega Herlinda ${ }^{1}$, Aripin ${ }^{2}$, Nurfadilah Siregar ${ }^{3}$ \\ ${ }^{1}$ Universitas Siliwangi, Jln. Siliwangi No. 24, Tasikmalaya 46115, Jawa Barat, Indonesia, \\ megahrlnda16@gmail.com \\ ${ }^{2}$ Universitas Siliwangi, Jln. Siliwangi No. 24, Tasikmalaya 46115, Jawa Barat, Indonesia, \\ aripin@unsil.ac.id \\ ${ }^{3}$ Universitas Siliwangi, Jln. Siliwangi No. 24, Tasikmalaya 46115, Jawa Barat, Indonesia, \\ nurfadilahsiregar@unsil.ac.id
}

\begin{abstract}
ABSTRAK
Tujuan penelitian ini yaitu mendeskripsikan proses berpikir kritis dan kesalahan siswa dalam pemecahan masalah matematika ditinjau dari tipe kepribadian dominance dan kepribadian influence. Metode penelitian yang digunakan adalah penelitian deskriptif kualitatif. Hasil penelitian menunjukkan bahwa: 1) Siswa dengan kepribadian dominance belum memenuhi semua indikator proses berpikir kritis yaitu pada tahap inferensi, strategi, dan salah satu siswa dominance lainnya tidak melalui tahap klarifikasi, serta pada saat pemecahan masalah terjadi kesalahan yaitu kesalahan dalam memahami masalah, transformasi, keterampilan proses dan penulisan jawaban. 2) Siswa dengan kepribadian influence memenuhi semua indikator proses berpikir kritis, namun pada saat memecahkan masalah terjadi kesalahan dalam keterampilan proses dan penulisan jawaban. Jadi, diantara kedua kepribadian tersebut yang melalui semua tahapan proses berpikir kritis dan terjadi sedikit kesalahan dalam pemecahan masalah yaitu siswa dengan kepribadian influence. Implikasi dari penelitian ini yaitu guru lebih memperhatikan dan memahami tipe kepribadian siswa agar proses berpikir yang semula dianggap kurang berjalan dengan baik dapat dikembangkan dengan maksimal.
\end{abstract}

Kata kunci: Proses Berpikir Kritis, Kesalahan, Kepribadian.

\begin{abstract}
The aim of this research is to describe the critical thinking process and student errors in solution of mathematics problems viewed from type dominance personality and influence personality. The research method is descriptive qualitative. Research result show that: 1) Students with dominance personality have not met all the indicators of critical thinking process, namely at the stage of inference, strategy, and one of the other dominance students did not through the clarification stage, and at the time of problem solving, errors occurred, namely errors in understanding problems, transformation, process skill, and writing. 2) Students with influence personality met all indicators of critical thinking process, but when solving problem, influence students make errors in processing skills and writing answers. So, between two personalities who went through all stage of the critical thinking process and made a few errors is students with an influence personality. Implication of this research is the teacher pays more attention to and understands the personality types of students so that the initial thought process is deemed not going well.
\end{abstract}

Keyword(s): Critical Thinking Process, Errors, Personality. 
How to Cite: Herlina, M., Aripin., \& Siregar, N. (2020). Proses Berpikir Kritis dan Kesalahan Siswa Dalam Pemecahan Masalah Matematika Ditinjau Dari Tipe Kepribadian Dominance-Influence. Mathline: Jurnal Matematika dan Pendidikan Matematika, Vol. 5 No. 2, 154-171.

DOI: https://doi.org/10.31943/mathline.v5i2.161

\section{PENDAHULUAN}

Proses berpikir kritis berkaitan dengan pemecahan masalah. Aktivitas pemecahan masalah menyediakan menjadi pemicu berkembangnya berpikir kritis siswa (Cahyono, 2015). Berpikir kritis lebih kompleks dari berpikir biasa pada umumnya (Sari, 2017; Amir, 2015) dan termasuk dalam kemampuan berpikir tingkat tinggi yang harus dikuasai dalam pendidikan ke-21 (Tivani, Wibowo, \& Nugraheni, 2019). Oleh karena itu, berpikir kritis harus menjadi tujuan dalam pembelajaran (Jacob, 2012; Tivani et al., 2019). Selain itu, Zhou, Huang, \& Tian (2013) mengungkapkan bahwa berpikir kritis merupakan bagian yang tidak dapat dipisahkan dari pendidikan, namun bukan berarti menjadi suatu pilihan dalam pendidikan. Berdasarkan hasil observasi awal yang dilakukan oleh Rusdiana \& Sucipto (2018) bahwa kemampuan menganalisis dan mengevaluasi dalam mengerjakan soal matematika belum optimal, sehingga kemampuan berpikir kritis matematis siswa masih kurang. Hal tersebut disebabkan oleh strategi pembelajaran yang diterapkan belum mengembangkan berpikir tingkat tinggi. Mengevaluasi proses berpikir kritis peserta didik bukanlah hal mudah bagi pendidik (Men, 2017; Septyani \& Siswono, 2018). Hal tersebut dikemukakan oleh Rasiman (2013) bahwa kenyataan di lapangan tidak mudah mengetahui proses berpikir kritis melalui pembelajaran matematika karena guru lebih fokus pada hasil belajar peserta didik. Hasil penelitian (Retnowati, Sujadi, \& Subanti, 2016) bahwa peserta didik kurang mampu menjelaskan hasil proses penalaran tentang langkah pemecahan masalah dengan alasan logis dan menemukan alternatif lain, sehingga hanya peserta didik yang berkemampuan awal matematika tinggi saja yang mampu berpikir kritis pada setiap tahapan proses berpikir kritis.

Pada saat berpikir kritis, seseorang akan melalui suatu tahapan berpikir salah satunya yaitu tahapan proses berpikir kritis menurut Jacob \& Sam (2008) yang terdiri dari tahap klarifikasi, tahap asesmen, tahap inferensi, dan tahap strategi. Berikut ini tabel tahapan proses berpikir kritis peserta didik yang dikemukakan oleh Jacob \& Sam (2008) dan Ardani \& Ismail (2016) dalam memecahkan masalah: 
Tabel 1. Tahapan Proses Berpikir Kritis

Tahapan Proses Berpikir Kritis

\section{Klarifikasi}

(Merumuskan masalah dengan tepat dan jelas
Asesmen

(Mengangkat pertanyaan masalah penting dalam soal)

\section{Inferensi}

(Membuat kesimpulan berdasarkan informasi yang telah diperoleh)

1. Peserta didik merumuskan poko permasalahan terkait soal yang digunakan dalam penyelesaian masalah.

2. Peserta didik mengumpulkan informasi yang diketahui dan ditanyakan dalam permasalahan penyelesaian masalah.

3. Peserta didik mendefinisikan kata kunci yang terkait dengan permasalahan.

1. Peserta didik mengidentifikasi informasi-informasi yang relevan dan tidak relevan dalam permasalahan yang digunakan dalam penyelesaian masalah.

2. Peserta didik mempertimbangkan alasan-alasan terkait dengan informasi relevan dan tidak relevan yang telah ditemukan untuk penyelesaian masalah.

1. Peserta didik menggunakan informasi yang relevan untuk menyelesaikan masalah.

2. Peserta didik menggali pengetahuan yang telah diperoleh sebelumnya.

3. Peserta didik menyusun langkah-langkah yang akan digunakan untuk menyelesaikan masalah.

4. Peserta didik dapat menjelaskan bagaimana hubungan tiap informasi yang ada.

Strategi

(Berpikir

terbuka

menyelesaikan

masalah)
1. Peserta didik melaksanakan pemecahan masalah dengan secara menggunakan informasi-informasi yang telah dikumpulkan dalam sesuai dengan langkah yang telah direncanakan.

2. Peserta didik mengevaluasi langkah-langkah yang mungkin kemudian memprediksi hasil langkah-langkah diusulkan.

Sumber: modifikasi dari Jacob \& Sam (2008) dan Ardani \& Ismail (2016)

Hasil pra penelitian yang dilakukan oleh peneliti menunjukkan bahwa belum terpenuhinya semua tahapan-tahapan proses berpikir kritis yang dilakukan oleh peserta didik dalam memecahkan masalah program linear. Sesuai dengan pernyataan Khamidah \& Suherman (2016) bahwa kebanyakan peserta didik kurang memperhatikan langkahlangkah penyelesaian karena peserta didik hanya mementingkan hasil akhir jawaban sehingga banyak langkah-langkah yang tidak ditempuh. Selain itu masalah yang sering dihadapi oleh peserta didik dalam menyelesaikan program linear yaitu mengubah permasalahan kontekstual ke dalam model matematika. Hal ini sesuai dengan hasil 
observasi Hidayah (2016) bahwa banyak kesalahan yang dilakukan oleh peserta didik yaitu tidak menuliskan pemisalan variabel yang akan digunakan untuk membuat model matematika, sehingga tidak sedikit peserta didik yang melakukan kesalahan ketika menyelesaikan model matematika yang telah dibuat. Kesalahan jawaban peserta didik terjadi karena proses menerima dan mengorganisasi informasi yang tidak tepat namun tetap digunakan untuk alasan menjawab (Hidayat, Sugiarto, \& Pramesti, 2013). Menurut Wati et al. (2017) dan Lusiana (2017) perlu mendapat perhatian dan diidentifikasi sejauh mana penugasan peserta didik terhadap materi dilakukan, serta mengetahui mengapa kesalahan tersebut dilakukan (Hidayat et al., 2013; Widodo, 2013; Siswandi, Sujadi, \& Riyadi, 2016).

Salah satu alat yang dapat digunakan untuk mengidentifikasi kategori kesalahan terhadap jawaban dari sebuah tes uraian yaitu dengan prosedur Newman yang terdiri dari membaca, memahami, transformasi, keterampilan proses, dan penulisan jawaban (Haryati, Suyitno, \& Junaedi, 2016). Prosedur Newman merupakan metode yang menganalisis kesalahan dalam soal cerita, sehingga peneliti memilih menggunakan prosedur Newman untuk menganalisis kesalahan peserta didik karena soal yang diberikan adalah soal cerita dengan materi program linear sehingga menggunakan analisis yang kompleks dimulai dari membaca sampai ke penulisan jawaban akhir. Oleh karena itu, analisis yang tepat untuk kesalahan peserta didik dalam memecahkan masalah program linear yaitu analisis kesalahan Newman. Selain itu, Analisis kesalahan Newman memberikan kerangka untuk mempertimbangkan alasan yang mendasari tentang kesulitan yang dialami peserta didik dalam menyelesaikan soal cerita ( Ismunandar et al., 2019; Karnasih, 2015). Berikut ini tabel untuk faktor dan indikator penyebab kesalahan menurut prosedur Newman:

Tabel 2. Faktor dan Indikator Penyebab Kesalahan

\section{Faktor Penyebab} Kesalahan
Membaca
1. Peserta didik tidak mampu membaca atau mengenali simbol.
2. Peserta didik tidak mampu memaknai arti setiap kata, istilah atau simbol dalam soal.
Memahami
1. Peserta didik tidak memahami informasi apa saja yang diketahui dalam soal dengan lengkap.
2. Peserta didik tidak memahami apa saja yang ditanyakan dalam soal dengan lengkap.
Transformasi 1. Peserta didik tidak mampu membuat model matematika dari informasi yang diperoleh. 


\begin{tabular}{cc}
\hline $\begin{array}{c}\text { Faktor Penyebab } \\
\text { Kesalahan }\end{array}$ & \multicolumn{1}{c}{ Indikator } \\
\hline & $\begin{array}{c}\text { 2. Peserta didik tidak mengetahui rumus yang akan digunakan } \\
\text { untuk menyelesaikan soal. }\end{array}$ \\
& $\begin{array}{l}\text { 3. Peserta didik tidak mengetahui operasi hitung yang akan } \\
\text { digunakan untuk menyelesaikan soal. }\end{array}$ \\
Keterampilan Proses & $\begin{array}{l}\text { Peserta didik tidak mengetahui prosedur atau langkah-langkah } \\
\text { yang akan digunakan untuk menyelesaikan soal dengan tepat. }\end{array}$ \\
Penulisan Jawaban & $\begin{array}{l}\text { 1. Peserta didik tidak mampu menemukan hasil akhir dari soal } \\
\text { berdasarkan prosedur atau langkah-langkah yang telah } \\
\text { digunakan. }\end{array}$ \\
& $\begin{array}{l}\text { 2. Peserta didik tidak dapat menunjukkan jawan akhir dari } \\
\text { penyelesaian soal dengan benar. }\end{array}$ \\
\hline
\end{tabular}

Sumber: diadopsi dari Sughesti, Muhsetyo, \& Susanto (2016)

Menurut Mulyodoro (2017) banyak faktor yang mempengaruhi adanya perbedaan dalam memahami permasalahan salah satunya adalah kepribadian. Hasil penelitian (Sunarto \& Sagirani, 2011) menunjukkan bahwa proses berpikir setiap peserta didik berbeda dilihat dari tipe kepribadian yang berbeda. Pada saat menyelesaikan soal matematika, setiap peserta didik dimungkinkan mempunyai cara berpikir yang berbeda sebagai akibat dari perbedaan sifat yang dimiliki oleh setiap individu (Susanti \& Setianingsih, 2014). Perbedaan tersebut didasarkan dengan pendekatan penggolongan kepribadian (Sunarto, Budayasa, \& Juniati, 2017). Ada berbagai tes kepribadian di Indonesia di antaranya MMPI, 16 PF, EPPS, DISC, dan NSQ (Periantalo \& Azwar, 2017). Dalam penelitian ini, penelitian menggunakan DISC yang merupakan penggolongan kepribadian yang diperkenalkan oleh Dr. William Moulton Marstor pada tahun 1928 di antaranya kepribadian dominance, influence, steadiness, dan compliance. Berikut ini tabel tipe kepribadian DISC beserta karakteristiknya:

\section{Tabel 3. Tipe Kepribadian dan Karakteristiknya}

Tipe Kepribadian

Dominance

Influence

\section{Karakteristik}

Peserta didik yang menyukai hal-hal baru, suka bersaing dan ditantang, pemberani, cepat dan senang mengambil keputusan, tidak mudah menyerah, senng menyelesaikan masalah, berorientasi pada hasil daripada proses karena tidak suka detai dan selalu berpikir secara garis besar, dan mengambil resiko.

Kecenderungan kepribadian ini ketika berada di bawah tekanan yaitu memaksakan kehendak kepada orang lain, egois, agresif, dan berargumen untuk menunjukkan diri benar.

Peserta didik yang penuh percaya diri, hangat, senang sekali berbicara, gaya dan cara bicara meyakinkan, antusias dan bersemangat, persuasive, mudah bergaul, pelupa, tidak suka yang 


\begin{tabular}{ll}
\hline Tipe Kepribadian & \multicolumn{1}{c}{ Karakteristik } \\
\hline & terstruktur sehingga membenci detail dan angka, dan mudah \\
& percaya dengan perkataan orang lain. \\
& Kecenderungan kepribadian ini ketika berada dibawah tekanan \\
& yaitu terlalu optimis, banyak bicara, dan tidak realistis. \\
& Peserta didik yang santai, tidak khawatir, akan membutuhkan lebih \\
& banyak waktu untuk menyelesaikan suatu hal karena cara \\
& berpikirnya yang selangkah demi selangkah, stabil dan terprediksi, \\
& banyak berpikir sebelum berbicara sehingga mudah tertekan, dan \\
& tidak banyak menunjukkan ekspresi di wajah. \\
& Peserta didik yang analitis, akurat, detail, ingin melakukan sesuatu \\
& dengan benar, relative sabar, stabil dalam melakukan sesuatu yang \\
& sesuai dengan prosedurnya, menyelesaikan masalah secara \\
& menyeluruh, fokus pada pekerjaan, dan senang sekali dengan angka \\
& serta data.
\end{tabular}

Sumber: adopsi dari Shin (2013)

Tes DISC pada umumnya digunakan dalam dunia kerja karena bertujuan untuk melihat dan mengukur perilaku kerja yang berdasarkan pada 4 tipe kepribadian (Setiawati, Abdillah, \& Hadiana, 2016; Wardy \& Djamil, 2019). Hal serupa dikemukakan oleh Susilawati \& Silviandari (2012) bahwa kepribadian DISC banyak digunakan untuk setting kerja dan organisasi. Oleh karena itu, peneliti ingin meneliti mengenai kepribadian DISC pada bidang pendidikan matematika karena masih sedikit yang meneliti kepribadian tersebut. Selain itu, pada saat penelitian dari tiga kelas yang peneliti tes menggunakan angket tes profil DISC hanya 2 peserta didik mempunyai kepribadian dominance dan 2 peserta didik mempunyai kepribadian influence serta masih sedikit jurnal yang meneliti kedua kepribadian tersebut dalam pendidikan matematika yang peneliti temukan. Beberapa sumber yang meneliti kepribadian dominance dalam pendidikan matematika yaitu penelitian Septevani (2017) dan Febriana, Zulyadaini, \& Aisyah (2018), sedangkan penelitian terhadap kepribadian influence peneliti hanya menemukan penelitian (Rohati, 2014). Selain itu, menurut Shin (2013) bahwa Indonesia termasuk negara yang bertipe kepribadian steadiness. Berdasarkan beberapa hal tersebut peneliti tertarik melakukan penelitian terhadap kepribadian dominance dan influence dalam proses berpikir kritis dan kesalahan yang dilakukannya. Tujuan dari penelitian ini yaitu mendeskripsikan proses berpikir kritis dan kesalahan peserta didik dalam memecahkan masalah matematika ditinjau dari tipe kepribadian dominance dan kepribadian influence.

\section{METODE PENELITIAN}

Metode yang digunakan dalam penelitian ini yaitu penelitian deskriptif kualitatif dengan jenis penelitan yaitu studi kasus. Dalam penelitian ini, peneliti mendeskripsikan tentang proses berpikir kritis dan kesalahan yang dilakukan peserta didik dalam memecahkan masalah matematika ditinjau dari tipe kepribadian dominance dan kepribadian influence. 
Subjek dalam penelitian ini yaitu peserta didik kelas XI SMA Negeri 6 Tasikmalaya yang dipilih sebanyak empat subjek penelitian dengan masing-masing dua subjek dengan tipe kepribadian dominance dan dua subjek dengan tipe kepribadian influence. Dalam penelitian ini, subjek diberikan angket tes profil DISC terlebih dahulu untuk mengetahui setiap kepribadian dari masing-masing peserta didik. Dari hasil tes tersebut, kemudian masing-masing peserta didik tersebut diambil empat peserta didik dengan kepribadian yang berbeda untuk dijadikan subjek penelitian yaitu masing dua subjek dengan kepribadian dominance dan dua subjek dengan kepribadian influence. Teknik pemilihan subjek dilakukan secara purposive sampling. Subjek dipilih berdasarkan hasil dari tes profil DISC, dimana subjek hanya mempunyai satu kepribadian dan mempunyai kategori tinggi atau sangat tinggi diantara keempat tipe kepribadian DISC tersebut. Hal tersebut ditinjau dari grafik most dan least jika keduanya menunjukkan salah satu tipe kepribadian yang memiliki kategori tinggi maupun sangat tinggi dibandinkan dengan tipe kepribadian yang lain, maka subjek tersebut yang dijadikan sebagai subjek penelitian untuk memecahkan masalah program linear dan melakukan wawancara.

Instrumen penelitian yang digunakan yaitu peneliti sendiri, angket tes profil DISC, soal tes pemecahan masalah dengan materi program linear, dan pedoman wawancara. Soal tes pemecahan masalah divalidasi oleh dua orang dosen Pascasarjana Pendidikan Matematika, sedangkan Angket tes profil DISC yang digunakan yaitu diadopsi dari artikel ilmiah Sari (2018) yang berjudul "Analisis Kesalahan Siswa Tipe Kepribadian Compliance dalam Menyelesaikan Soal Matematika di SMK Negeri 3 Kota Jambi”. Dalam artikel tersebut dijelaskan bahwa tes profil DISC diadopsi langsung dari buku Shin (2013) yang berjudul "The DISC Codes", sehingga tidak dilakukan proses validasi lagi karena sudah mengalami sejumlah pengujian. Teknik pengumpulan data diperoleh dari tes kepribadian, tes pemecahan masalah, dan wawancara tidak terstruktur, sedangkan teknik analisis data terdiri dari reduksi data, penyajian data, dan penarikan kesimpulan. 


\section{HASIL DAN PEMBAHASAN}

Berikut ini soal pemecahan masalah dengan materi program linear yang diberikan kepada setiap subjek penelitian.

\footnotetext{
Sebuah perusahaan membuat 2 macam tas yaitu tas dengan merk ANGRY BIRDS dan tas dengan merk SPONGEBOB. Untuk membuat tas tersebut perusahaan memiliki mesin, yaitu mesin A khusus untuk memberi logo ANGRY BIRDS, mesin B khusus untuk memberi logo SPONGEBOB dan mesin C untuk menjahit tas dan memasang ritsleting. Setiap lusin tas merk ANGRY BIRDS mula-mula dikerjakan di mesin A selama 2 jam, kemudian dikerjakan di mesin C selama 6 jam. Tas dengan merk SPONGEBOB dikerjakan di mesin B selama $3 \mathrm{jam}$, kemudian di mesin C selama 5 jam. Jam kerja maksimum setiap hari untuk mesin A adalah 8 jam, mesin B adalah 15 jam, dan mesin $\mathrm{C}$ adalah $30 \mathrm{jam}$. Laba terhadap penjualan setiap lusin tas merk ANGRY BIRDS adalah \$3, sedangkan merk SPONGEBOB adalah \$5.

a. Tuliskan unsur-unsur yang diketahui dan ditanyakan!

b. Buatlah model matematika dari keterangan tersebut, kemudian selesaikan sesuai dengan konsep yang telah dipelajari secara rinci!

c. Berapa lusin sebaiknya tas merk ANGRY BIRDS dan tas merk SPONGEBOB yang dibuat agar bisa memaksimumkan laba?
}

\section{Gambar 1. Soal Pemecahan Masalah Program Linear}

Selain itu, berikut ini tabel keterangan gambar yang digunakan untuk alur penyelesaian setiap subjek penelitian.

\section{Tabel 4. Tabel Keterangan Gambar}

\begin{tabular}{|c|c|c|c|c|c|}
\hline $\begin{array}{l}\text { Kode } \\
\text { Grafik }\end{array}$ & Keterangan & $\begin{array}{l}\text { Kode } \\
\text { Grafik }\end{array}$ & Keterangan & $\begin{array}{l}\text { Kode } \\
\text { Grafik }\end{array}$ & Keterangan \\
\hline & $\begin{array}{l}\text { Tahap } \\
\text { klarifikasi }\end{array}$ & & $\begin{array}{l}\text { Tahap } \\
\text { membaca }\end{array}$ & 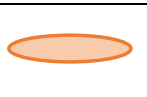 & $\begin{array}{l}\text { Kesalahan } \\
\text { membaca }\end{array}$ \\
\hline & Tahap asesmen & & $\begin{array}{l}\text { Tahap } \\
\text { memahami } \\
\text { Masalah }\end{array}$ & & $\begin{array}{l}\text { Kesalahan } \\
\text { memahami } \\
\text { masalah }\end{array}$ \\
\hline & Tahap inferensi & & $\begin{array}{l}\text { Tahap } \\
\text { transformasi } \\
\text { Tahap }\end{array}$ & & $\begin{array}{l}\text { Kesalahan } \\
\text { transformasi } \\
\text { Kesalahan }\end{array}$ \\
\hline & Tahap strategi & & $\begin{array}{l}\text { keterampilan } \\
\text { proses }\end{array}$ & & $\begin{array}{l}\text { keterampilan } \\
\text { proses }\end{array}$ \\
\hline & Soal & & Tahap & & Kesalahan \\
\hline & $\begin{array}{l}\text { Pemecahan } \\
\text { Masalah }\end{array}$ & 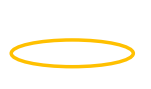 & $\begin{array}{l}\text { penulisan } \\
\text { jawaban }\end{array}$ & & $\begin{array}{l}\text { penulisan } \\
\text { jawaban }\end{array}$ \\
\hline
\end{tabular}

Berdasarkan hasil analisis proses berpikir kritis dan kesalahan yang dilakukan subjek dengan kepribadian dominance (SD) dan subjek dengan kepribadian influence (SI), yaitu sebagai berikut: 


\section{Subjek dengan Kepribadian Dominance}

Alur dari proses berpikir kritis dan kesalahan yang dilakukan oleh subjek 1 dan 2 dengan kepribadian dominance $\left(\mathrm{SD}_{1}\right.$ dan $\left.\mathrm{SD}_{2}\right)$ dalam memecahkan masalah matematika, yaitu sebagai berikut:

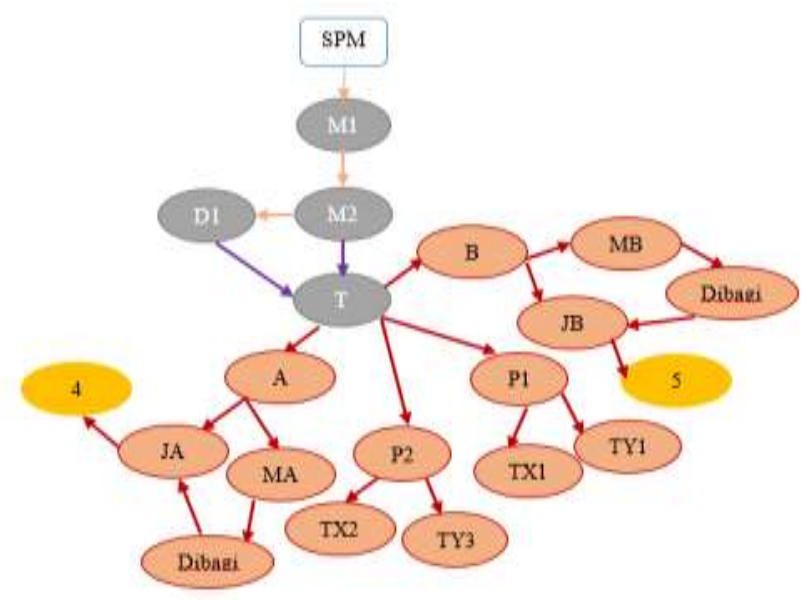

Gambar 2. Alur Penyelesaian Soal oleh SD1

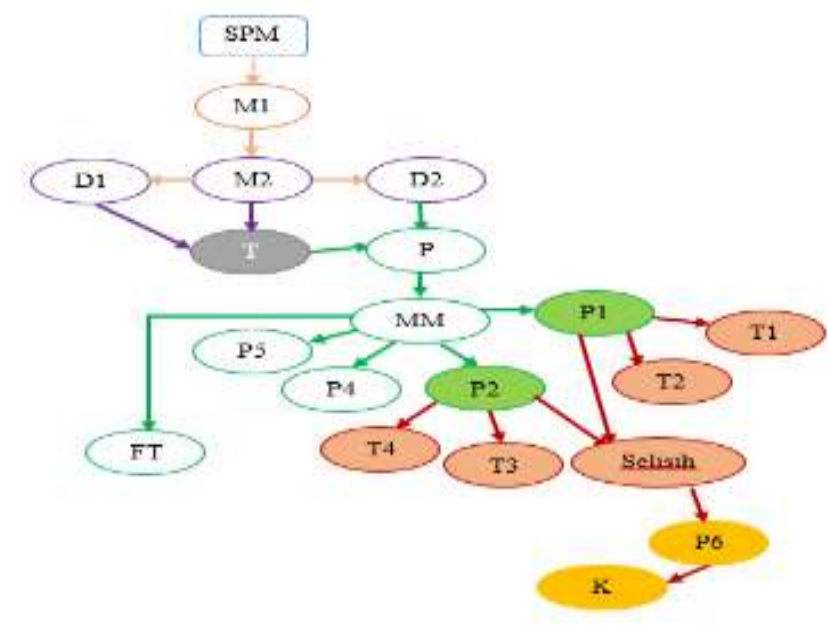

Gambar 3. Alur Penyelesaian Soal oleh $\mathrm{SD}_{2}$

Gambar 1 dan 2 menunjukkan alur penyelesaian proses berpikir kritis dan kesalahan yang dilakukan oleh subjek dominance. Berikut hasil analisisnya:

Pada tahap klarifikasi, hanya satu subjek dominance $\left(\mathrm{SD}_{2}\right)$ yang mampu memahami masalah dengan mengumpulkan informasi yang diketahui dan ditanyakan secara cepat, detail, dan sistematis. Hal ini sesuai dengan pernyataan Susilawati \& Silviandari (2012) bahwa tipe dominance cenderung cepat mengambil keputusan dalam pengumpulan informasi secara cepat dan detail. Namun tidak berlaku untuk $\mathrm{SD}_{1}$ yang hanya menuliskan sebagian informasi yang diketahui dan tidak menuliskan menuliskan informasi yang ditanyakan karena berdasarkan hasil wawancara subjek terburu-buru sehingga lupa tidak 
menuliskan unsur yang ditanyakan. Hal ini sesuai dengan ciri-ciri kepribadian dominance yang dijelaskan oleh Susilawati \& Silviandari (2012) bahwa tipe dominance cenderung tergesa-gesa terhadap suatu hal. Pada tahap ini kedua subjek tidak mampu memaknai arti dari setiap kata, istilah, atau simbol dalam soal artinya peserta didik melakukan kesalahan membaca, sehingga mengakibatkan kesalahan pada tahap selanjutnya.

Pada tahap asesmen hanya satu subjek yang mampu mengidentifikasi informasi yang relevan dan tidak relevan dalam permasalahan $\left(\mathrm{SD}_{2}\right)$, namun keduanya melakukan kesalahan pada saat menuliskan informasi ke dalam tabel walaupun sebenarnya subjek mampu menuliskan informasi yang relevan, terlihat dari kotretan yang dibuat subjek. Kesalahan tersebut disebut kesalahan memahami masalah dan terjadi karena subjek kurang memahami informasi. Berdasarkan hasil wawancara, subjek dominance terkecoh dengan banyaknya informasi dan kurang yakin bahwa informasi yang dituliskan cukup atau tidak karena tujuan yang digunakan kedua subjek tidak sesuai dengan masalah yang diberikan soal.

Pada tahap inferensi kedua subjek tidak mampu menuliskan maupun menjelaskan mengenai langkah-langkah penyelesaian yang akan digunakan untuk menyelesaikan masalah pada tahap strategi. Selain itu, salah satu subjek dominance $\left(\mathrm{SD}_{1)}\right.$ tidak membuat pemisalan variabel x dan y, namun kedua subjek dominance tersebut melakukan kesalahan yang sama dalam membuat tabel. Hal ini sesuai dengan hasil penelitian Septevani (2017) bahwa model yang digambarkan subjek dominance kategori tinggi kurang tepat sehingga berpengaruh pada tahap selanjutnya. Selain itu, menurut hasil observasi Hidayah (2016) bahwa banyak kesalahan yang dilakukan peserta didik yaitu tidak menuliskan pemisalan variabel yang akan digunakan untuk membuat model matematika, sehingga tidak sedikit peserta didik yang melakukan kesalahan ketika menyelesaikan model matematika yang telah dibuat. Pada saat wawancara subjek mampu memisalkan variabel $\mathrm{x}$ dan $\mathrm{y}$, namun karena keduanya terkecoh dengan banyaknya informasi yang diberikan oleh soal maka keduanya melakukan kesalahan transformasi. Hal ini dijelaskan oleh Sughesti et al. (2016) bahwa kesalahan transformasi terjadi ketika peserta didik tidak mampu membuat model matematis dari informasi yang diperoleh.

Pada tahap strategi kedua subjek dominance tidak mampu menyelesaikan masalah dengan tepat sesuai dengan konsep materi program linear. Terlihat pada hasil tes tertulis dan wawancara bahwa subjek hanya menggunakan logika dalam menyelesaikan dan langsung menuliskan jawaban akhir. Hal ini sesuai dengan pernyataan Septevani (2017) bahwa subjek dominance menggunakan strategi yang tidak tepat dalam menyelesaikan 
masalah karena subjek cenderung menggunakan intuisi dan hanya menebak jawaban. Pada tahap ini kedua subjek hanya mampu mencari titik koordinat pada setiap persamaan, namun titik koordinat yang diperoleh salah dikarenakan pada tahap sebelumnya kedua subjek melakukan kesalahan dalam membuat model matematika. Pada saat mengerjakan kedua subjek tampak serius dan bingung dengan apa yang harus dikerjakan selanjutnya, sehingga pada akhirnya subjek langsung menuliskan dengan melewati beberapa tahap sebelumnya. Hal ini sesuai dengan apa yang yang dijelaskan oleh Septevani (2017) bahwa dalam menyelesaikan soal, rata-rata subjek dominance tampak serius dan fokus dalam menyelesaikan soal namun sesekali terlihat bingung dalam mengerjakannya. Menurut Susilawati \& Silviandari (2012) bahwa dasar pengambilan keputusan yang dilakukan oleh subjek dengan kepribadian dominance yaitu pencapaian hasil menjadi prioritas.

\section{Subjek dengan Kepribadian Influence}

Alur dari proses berpikir kritis dan kesalahan yang dilakukan oleh subjek 1 dan 2 dengan kepribadian influence ( $\mathrm{SI}_{1}$ dan $\mathrm{SI}_{2}$ ) dalam memecahkan masalah matematika, yaitu sebagai berikut:

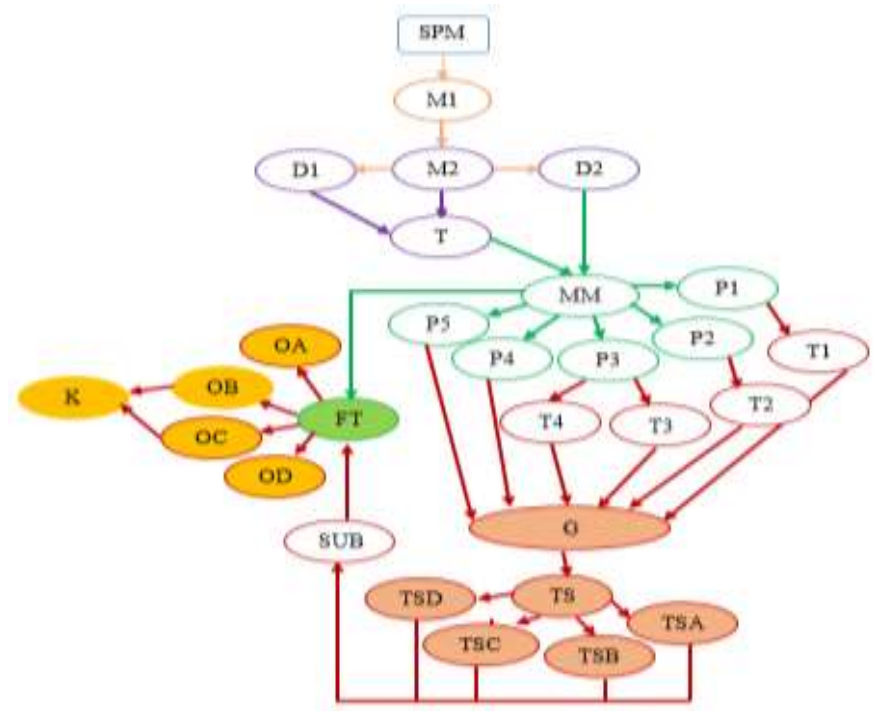

Gambar 4. Alur Penyelesaian Soal oleh SI1 


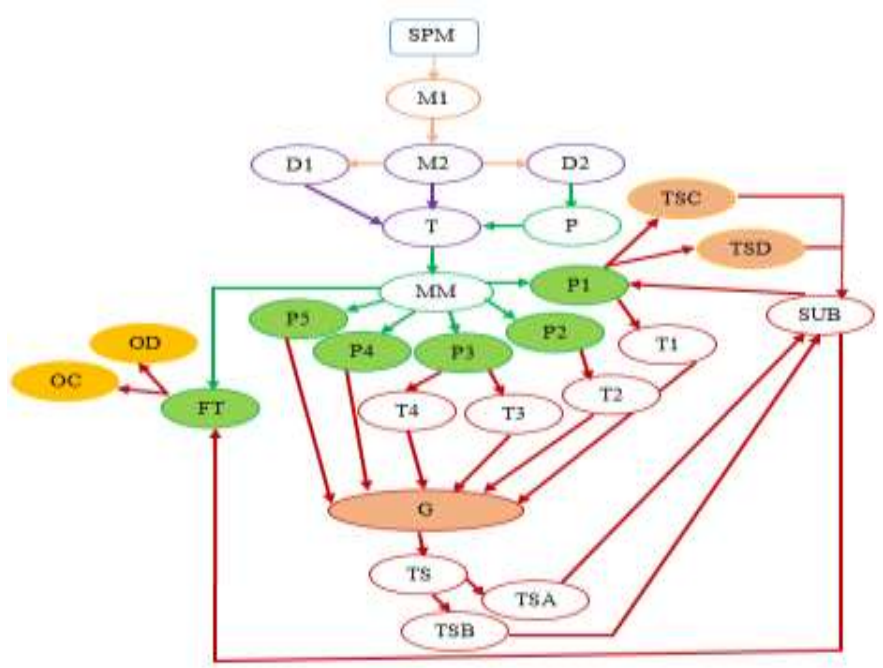

Gambar 5. Alur Penyelesaian Soal oleh $\mathrm{SI}_{2}$

Gambar 3 dan 4 menunjukkan alur penyelesaian proses berpikir kritis dan kesalahan yang dilakukan oleh subjek influence. Berikut hasil analisisnya:

Pada tahap klarifikasi kedua subjek influence membaca soal dengan cara bergumam kecil. Terlihat bahwa influence tidak bisa diam walaupun pada saat tes hanya bergumam yang bisa dilakukannya. Hal ini sesuai dengan karakteristik subjek influence menurut Shin (2013) yaitu penuh percaya diri dan senang berbicara. Kedua subjek mampu memahami makna dari kata atau istilah yang terdapat dalam soal dan mampu memahami masalah dengan mengumpulkan informasi yang diketahui dan ditanyakan secara detail. Hal ini sesuai dengan hasil penelitian Octaviani, Hartoyo, \& Sayu (2018) bahwa subjek yangb mempunyai sifat optimis dan antusias ini mampu memahami soal dengan mengetahui apa yang diketahui dan ditanyakan secara lengkap. Pada saat mengerjakan soal kedua subjek terlihat bingung dan ragu dalam menuliskan informasi dengan sesekali melihat lembar soal karena tidak mengetahui cara menuliskan kedua informasi tersebut. Hal ini sesuai dengan hasil penelitian Rohati (2014) bahwa pada tahap memahami masalah subjek influence mampu menyebutkan informasi yang diketahui dan ditanyakan dengan cepat, lancar, sambil sesekali melihat lembar soal.

Pada tahap asesmen kedua subjek influence mampu mengidentifikasi informasi yang relevan dan tidak relevan dengan cara membuat tabel informasi. Selain itu, kedua subjek mampu memahami apa yang diminta oleh soal dan merasa cukup dengan informasi yang ditulis walaupun pada saat membuat tabel informasi subjek terlihat bingung dengan informasi yang harus dimasukkan ke dalam tabel tersebut sehingga subjek menuliskannya terlebih dahulu di lembar kotretan. Hal ini sesuai dengan hasil penelitian Mayasari, Utomo, 
\& Cholily (2019) bahwa perencanaan yang disusun oleh peserta didik yang memiliki sifat optimis dan antusias ini sudah cukup untuk dijadikan pedoman untuk menyelesaikan soal. Rohati (2014) bahwa subjek influence mengetahui kecukupan syarat untuk memecahkan masalah yang diberikan pada tahap memahami masalah dan subjek mampu mengidentifikasi pengetahuan dasar apa saja yang dibutuhkan untuk memecahkan masalah, salah satunya membuat tabel informasi.

Pada tahap inferensi kedua subjek influence tidak menuliskan langkah-langkah penyelesaian, namun ketika diwawancarai keduanya mampu menjelaskan langkah-langkah yang digunakan untuk menyelesaikan masalah yang diberikan oleh soal. Hal ini sesuai dengan hasil penelitian Rohati (2014) bahwa peserta didik dengan kepribadian influence mampu menyusun rencana pemecahan masalah dengan memperkirakan strategi yang digunakan untuk menyelesaikan masalah. Selain itu, pada tahap inferensi subjek membuat model matematika, namun salah satu subjek influence $\left(\mathrm{SI}_{1}\right)$ tidak menuliskan pemisalan variabel $\mathrm{x}$ dan $\mathrm{y}$, sedangkan $\mathrm{SI}_{2}$ tidak menuliskan fungsi tujuan dikarenakan lupa. Kedua subjek mampu membuat model matematika, namun keduanya melakukan kesalahan yaitu $\mathrm{SI}_{1}$ membuat kesalahan dalam membuat fungsi tujuan dikarenakan mengikuti contoh soal yang pernah dipelajari dan $\mathrm{SI}_{2}$ melakukan kesalahan dalam memberikan tanda pertidaksamaan.

Pada tahap strategi kedua subjek influence mampu memecahkan masalah sesuai dengan langkah yang sudah direncanakan pada tahap sebelumnya. Pada saat wawancara kedua subjek mampu menyusun argumen mengenai cara yang digunakan untuk memecahkan masalah. Hal ini sesuai dengan hasil penelitian Rohati (2014) bahwa subjek influence dapat melaksanakan rencana pemecahan masalah dan menggunakan argument yang telah dipahami untuk digunakan sebagai langkah memecahkan masalah. Terlihat hasil pekerjaan kedua subjek melakukan kesalahan pada saat membuat grafik. Berdasarkan hasil wawancara yang menjadi penyebab kesalahan kedua subjek yaitu titik koordinat dari persamaan satu dan dua disatukan menjadi satu persamaan dan dibuat satu buah garis lurus karena mengira bahwa dalam membuat grafik itu setiap persamaan harus memuat variabel $\mathrm{x}$ dan y supaya bisa dibuat sebuah garis linear, sedangkan jawaban seharusnya persamaan satu dan persamaan dua diperoleh dari dua unsur masalah yang berbeda sehingga tidak bisa disatukan menjadi sebuah persamaan dan dari masing-masing persamaan tersebut harus digambar ke dalam grafik satu persatu meskipun pada setiap persamaannya hanya memuat satu variabel. Berdasarkan hasil wawancara, sebenarnya kedua subjek influence mampu membuat grafik walaupun dalam persamaannya hanya memuat satu variabel $\mathrm{x}$ maupun $\mathrm{y}$, 
namun karena lupa dan tidak pernah diterapkan akhirnya kedua subjek influence melakukan kesalahan dalam membuat grafik yang mengakibatkan kesalahan pada proses selanjutnya. Kesalahan yang dilakukan kedua subjek influence pada tahap strategi yaitu kesalahan keterampilan proses dan kesalahan penulisa jawaban. Berdasarkan hasil penelitian Rohati (2014) bahwa subjek influence cenderung melakukan kecerobohan dan tidak teliti dalam menyelesaikan soal.

Berdasarkan alur penyelesaian yang dilakukan oleh setiap subjek penelitian, berikut ini perbandingan alur penyelesaian yang dilakukan oleh setiap subjek dengan kepribadian dominance dan influence dengan alur penyelesaian yang dilakukan peneliti.

Tabel 5. Perbandingan Alur Penyelesaian Subjek Penelitian dengan Peneliti

\begin{tabular}{lccccc}
$\begin{array}{l}\text { Tahapan Proses Berpikir } \\
\text { Kritis \& Kesalahan }\end{array}$ & P & SD1 & SD2 & SI & SI2 \\
\hline Tahap Klarifikasi & M1 & M1 & M1 & M1 & M1 \\
1. Membaca & M2 & M2 & M2 & M2 & M2 \\
2. Memahami masalah & D1 & D1 & D1 & D1 & D1 \\
& D2 & - & D2 & D2 & D2 \\
Tahap Asesmen & T & T & T & T & T \\
1. Memahami masalah & & & & &
\end{tabular}

Tahap Inferensi

1. Transformasi

Tahap Strategi

1. Keterampilan proses

2. Penulisan jawaban

$\begin{array}{ccccc}\text { L } & - & - & - & - \\ \text { P } & - & \text { P } & - & \text { P } \\ \text { MM } & \text { MM } & \text { MM } & \text { MM } & \text { MM } \\ \text { P1 } & \text { P1 } & \text { P1 } & \text { P1 } & \text { P1 } \\ \text { P2 } & \text { P2 } & \text { P2 } & \text { P2 } & \text { P2 } \\ \text { P3 } & - & - & \text { P3 } & \text { P3 } \\ \text { P4 } & - & \text { P4 } & \text { P4 } & \text { P4 } \\ \text { P5 } & - & \text { P5 } & \text { P5 } & \text { P5 } \\ \text { FT } & & \text { FT } & \text { FT } & \text { FS } \\ \text { T1 } & \text { TX1, } & \text { T1, T5 } & \text { T1 } & \text { T1 } \\ & \text { TY1 } & & & \\ \text { T2 } & \text { TX2, } & \text { T2, T6 } & \text { T2 } & \text { T2 } \\ \text { T3 } & - & - & \text { T3 } & \text { T3 } \\ \text { T4 } & - & - & \text { T4 } & \text { T4 } \\ \text { G } & - & - & \text { G } & \text { G } \\ \text { TS } & - & - & \text { TS } & \text { TS } \\ \text { TSA } & - & - & \text { TSA } & \text { TSA } \\ \text { TSB } & - & - & \text { TSB } & \text { TSB } \\ \text { TSC } & - & - & \text { TSC } & \text { TSC } \\ \text { TSD } & - & - & \text { TSD } & \text { TSD } \\ \text { SUB } & \text { dibagi } & \text { Selisih } & \text { SUB } & \text { SUB } \\ \text { OA } & \text { MA:JA } & \text { P1-p2 } & \text { OA } & - \\ \text { OB } & \text { MB:JB } & - & \text { OB } & - \\ \text { OC } & - & - & \text { OC } & \text { OC } \\ \text { OD } & - & - & \text { OD } & \text { OD } \\ \text { CL } & - & - & - & - \\ \text { B1 } & - & - & - & -\end{array}$




\begin{tabular}{cccccc}
\hline $\begin{array}{c}\text { Tahapan Proses Berpikir } \\
\text { Kritis \& Kesalahan }\end{array}$ & P & SD1 $_{1}$ & SD2 $_{2}$ & SI $_{1}$ & SI $_{2}$ \\
\hline & B2 & - & - & - & - \\
& LDP & - & - & - & - \\
& DP & - & - & - & - \\
& K & - & K & K & - \\
\hline
\end{tabular}

Keterangan: warna merah menunjukkan kesalahan yang dilakukan oleh subjek penelitian dalam memecahkan masalah program linear, sedangkan warna hitam menunjukkan jawaban benar sesuai dengan jawaban dari peneliti.

Berdasarkan tabel 5 terlihat bahwa semua subjek penelitian tidak menuliskan langkah-langkah penyelesaian dan tidak mencari cara lain lain dalam memecahkan masalah program linear. Hal ini sesuai dengan hasil penelitian Retnowati (2016) bahwa peserta didik kurang mampu menjelaskan hasil proses penalaran tentang langkah pemecahan masalah dengan alasan logis dan menemukan alternatif lain.

Dari permasalahan tersebut, adapun kelebihan dari penelitian ini yaitu variabel yang berkaitan dengan kepribadian DISC masih sedikit dilakukan oleh peneliti-peneliti lain. Selain itu, dalam penelitian ini peneliti tidak hanya meneliti tentang proses berpikir kritis atau kesalahan saja namun kedua-duanya diteliti dan dianalisis dengan cara menghubungkan antar kedua indokator antara proses berpikir kritis dan kesalahan. Dari beberapa hal tersebut bisa dijadikan sebagai keterbaharuan dalam penelitian. Kekurangan penelitian ini yaitu kurangnya sumber penelitian terdahulu tentang kepribadian dominance dan influence yang digunakan dalam pembahasan. Dalam masa pandemic covid 19 saat ini terdapat keterbasan peneliti dalam melakukan penelitian ini yaitu peneliti sedikit kesulitan dalam mengatur waktu penelitian dengan subjek penelitian karena padatnya jadwal peserta didik yang melakukan pembelajaran daring di sekolah, sehingga hanya sedikit waktu yang bisa diberikan peserta didik untuk melakukan penelitian ini dan secara otomatis peneliti tidak dapat leluasa melakukan penelitian karena waktu yang terbatas dan juga banyak batasan-batasan yang harus dilakukan oleh peneliti karena suasana covid 19 .

\section{KESIMPULAN}

Berdasarkan pembahasan di atas, maka dapat disimpulkan bahwa (1) Peserta didik dominance belum memenuhi semua indikator tahapan proses berpikir kritis di antaranya pada tahap kalrifikasi tidak menuliskan unsur yang ditanyakan dan melakukan kesalahan dalam memahami unsur yang diketahui $\left(\mathrm{SD}_{1}\right)$, pada tahap asesmen tidak menuliskan maupun menjelaskan langkah-langkah penyelesaian dan melakukan kesalahan dalam membuat model matematika, pada tahap strategi tidak mampu menyelesaikan masalah sampai selesai dan melakukan kesalahan selama proses dan penulisan jawaban. (2) Peserta didik dengan kepribadian influence telah memenuhi semua indikator proses berpikir kritis diantaranya pada tahap klarifikasi dan asesmen mampu memahami masalah dengan baik, 
pada tahap inferensi tidak menuliskan langkah-langkah penyelesaian namun mampu menjelaskan dalam wawancara, pada tahap strategi melakukan kesalahan dalam membuat grafik, proses pemecahan masalah lainnya, dan penulisan jawaban.

\section{UCAPAN TERIMAKASIH}

Penulis mengucapkan terimakasih kepada semua pihak yang telah berperan dalam penyusunan artikel penelitian ini, terutama peserta didik kelas XI SMA Negeri 6 Tasikmalaya, Dra. Elang Nurohmah selaku guru mata pelajaran, serta peserta didik yang menjadi subjek penelitian yang telah membantu dalam pelaksanaan penelitian ini, sehingga penelitian ini dapat terlaksana dengan baik.

\section{DAFTAR PUSTAKA}

Amir, M. F. (2015). Proses Berpikir Kritis Siswa Sekolah Dasar Dalam Memecahkan Masalah Berbentuk Soal Cerita Matematika Berdasarkan Gaya Belajar. Jurnal Math Educator Nusantara, 1, 159-170.

Ardani, S. H., \& Ismail. (2016). Profil Berpikir Kritis Siswa SMP Dalam Memecahkan Masalah Matematika Ditinjau Dari Gaya Kognitif Dan Jenis Kelamin. MathEdusa, 184-192.

Cahyono, B. (2015). Korelasi Pemecahan Masalah Dan Indikator Berfikir Kritis. Phenomenom, 5, 15-24.

Febriana, R., Zulyadaini, \& Aisyah. (2018). Analisis Kemampuan Berpikir Kritis Matmatis Siswa Berdasarkan Tipe Kepribadian Dominan Di Kelas XI MIA SMA Negeri 2 Kota Jambi. $\pi$ (Phi), 2, 33-39.

Haryati, T., Suyitno, A., \& Junaedi, I. (2016). Analisis Kesalahan Siswa SMP Kelas Vii Dalam Menyelesaikan Soal Cerita Pemecahan Masalah Berdasarkan Prosedur Newman. UJME: Unnes Journal of Mathematics Education, 5, 8-15.

Hidayah, S. (2016). Analisis Kesalahan Siswa Dalam Menyelesaikan Soal Cerita SPLDV Berdasarkan Langkah Penyelesaian Polya. Prosiding Seminar Nasional Pendidikan Matematika, 1, 182-190.

Hidayat, B. R., Sugiarto, B., \& Pramesti, G. (2013). Analisis Kesalahan Siswa Dalam Menyelesaikan Soal Pada Materi Ruang Dimensi Tiga Ditinjau Dari Gaya Kognitif Siswa (Penelitian Dilakukan Di SMA Negeri 7 Surakarta Kelas X Tahun Ajaran 2011/2012). Jurnal Pendidikan Matematika, 1, 39-46.

Ismunandar, D., Gunadi, F., \& Taufan, M. (2019). Analisis Kesalahan Siswa Berdasarkan Prosedur Newman pada Kemampuan Koneksi Matematis. Dialektika, 6(2), 144-164.

Jacob, S. M. (2012). Mathematical Achievement And Critical Thinking Skills In Asynchronous Discussion Forums. Procedia: Social and Behavioral Sciences, 1, 800804. https://doi.org/10.1016/j.sbspro.2011.12.144

Jacob, S. M., \& Sam, H. K. (2008). Measuring Critical Thinking In Problem Solving Through Online Discussion Forums In First Year University Mathematics. Proceeding of the International Multi Conference of Engineers and Computer Scientists, I, 19-21.

Karnasih, I. (2015). Analisis Kesalahan Newman Pada Soal Cerita Matematis (Newman's Error Analysis In Mathematical Word Problems). Jurnal PARADIKMA, 8, 37-51. 
Khamidah, K., \& Suherman. (2016). Proses Berpikir Matematis Siswa Dalam Menyelesaikan Masalah Matematika Ditinjau Dari Tipe Kepribadian Keirsey Khusnul. Al-Jabar: Jurnal Pendidikan Matematika, 7, 231-248.

Lusiana, R. (2017). Analisis Kesalahan Mahasiswa Dalam Memecahkan Masalah Pada Materi Himpunan Ditinjau Dari Gaya Kognitif. JPPM, 10, 24-29.

Mayasari, D., Utomo, D. P., \& Cholily, Y. M. (2019). Analisis Metakognisi Siswa Dalam Memecahkan Masalah Matematika Ditinjau Dari Tipe Kepribadian Hipocrates. JKPM: Jurnal Kajian Pembelajaran Matemtika, 3, 34-39.

Men, F. E. (2017). Proses Berpikir Kritis Siswa SMA Dalam Pengajuan Soal Matematika Berdasarkan Tingkat Kemampuan Matematika. Jurnal Dan Pendidikan Kebudayaan Missio, 9, 35-42.

Mulyodoro. (2017). Kemampuan Pemecahan Masalah Matematika Siswa SMP Kelas Viii Berdasarkan Tipe Kepribadian Keirsey Dalam Setting PBL. Under Graduates Thesis, Universitas Negeri Semarang, 1-54.

Octaviani, C., Hartoyo, A., \& Sayu, S. (2018). Proses Penyelesaian Masalah Berdasarkan Tahapan Polya Ditinjau Dari Tipe Kepribadian Siswa Kelas XI SMA. Jurnal Pendidikan Dan Pembelajaran Khatulistiwa, 7, 1-9.

Periantalo, J., \& Azwar, S. (2017). Pengembangan Skala Kepribadian Siswa SMA Dari Tipologi Kepribadian Jung Dan Myers-Briggs. Jurnal Sains Sosio Humaniora, 1, 191-207.

Rasiman. (2013). Proses Berpikir Kritis Siswa SMA Dalam Menyelesaikan Masalah Matematika Bagi Siswa Dengan Kemampuan Matematika Rendah. Prosiding Seminar Nasional Matematika Dan Pendidikan Matematika, 185-192.

Retnowati, D., Sujadi, I., \& Subanti, S. (2016). Proses Berpikir Kritis Siswa Kelas XI Farmasi Smk Citra Medika Sragen Dalam Pemecahan Masalah Matematika. Jurnal Elektronik Pembelajaran Matematika, 4, 105-116.

Rohati. (2014). Proses Berpikir Kritis Siswa SMP Tipe Influence Dalam Memecahkan Masalah Matematika. Edumatika, 4(1), 44-50.

Rusdiana, E., \& Sucipto. (2018). Peningkatan Kemampuan Berpikir Kritis Matematis Melalui Penerapan Model Cooperative Learning Tipe Group Investigation. Jurnal Ilmiah: SOULMATH, 6, 25-36.

Sari, F. M. (2018). Analisis Kesalahan Siswa Tipe Kepribadian Compliance Dalam Menyelesaikan Soal Matematika Di SMK Negeri 3 Kota Jambi. Respository: Universitas Jambi, 1-10.

Sari, R. E. (2017). Proses Berpikir Kritis Siswa Sekolah Dasar Pada Pembelajaran Geometri Melalui Pendekatan Matematika Realistik. Universitas Muhammadiyah Sidoarjo, 1-7.

Septevani, Y. S. (2017). Analisis Kemampuan Berpikir Kritis Siswa Dalam Pemecahan Masalah Matematika Dengan Tipe Kepribadian Dominance. Repository: Universitas Jambi, 1-10.

Septyani, D. A., \& Siswono, T. Y. E. (2018). Proses Berpikir Kritis Siswa SMP Dalam Pengajuan Masalah Matematika Berdasarkan Gaya Kognitif Visualizer Dan Verbalizer. MATHEdunesa: Jurnal Ilmiah Pendidikan Matematika, 2, 205-2013.

Setiawati, I., Abdillah, G., \& Hadiana, A. I. (2016). Sistem Pendukung Keputusan Penempatan Karyawan Berdasarkan Test Dominant-Influence-Steady-Compliance (Disc) Menggunakan Metode Profile Matching. Prosiding SNST: Fakultas Teknik Universitas Wahid Hasyim Semarang, 1, 25-30.

Siswandi, E., Sujadi, I., \& Riyadi. (2016). Analisis Kesalahan Siswa Dalam Menyelesaikan Masalah Matematika Kontekstual Pada Materi Segiempat Berdasarkan Analisis Newman Ditinjau Dari Perbedaan Gender (Studi kasus pada siswa kelas vii smpn 20 
surakarta). Jurnal Elektronik Pembelajaran Matematika, 4, 633-643.

Sughesti, M. M., Muhsetyo, G., \& Susanto, H. (2016). Jenis Kesalahan Siswa Dalam Menyelesaikan Soal Cerita Berdasarkan Prosedur Newman. ResearchGate, 563-572.

Sunarto, M. J. D., Budayasa, I. K., \& Juniati, D. (2017). Profile Proses Berpikir Mahasiswa Tipe Kepribadian Sensing Dalam Memecahkan Masalah Logika Matematika. Cakrawala Pendidikan: Jurnal Ilmiah Pendidikan, 36, 299-308.

Sunarto, M. J. D., \& Sagirani, T. (2011). The Thinking Process Profile The Students Of Informatics System Departement In Solving The Mathematics Problem Based On The Personality Type And Gender. Respository Universitas Dinamika, 1-10.

Susanti, R. D., \& Setianingsih, R. (2014). Kemampuan Siswa Dalam Menyelesaikan Soal Cerita Materi Sistem Persamaan Linear Dua Variabel Ditinjau Dari Tipe Kepribadian Ekstrover-Introver. MATHEdunesa: Jurnal Ilmiah Pendidikan Matematika, 3, 173180.

Susilawati, I. R., \& Silviandari, I. A. (2012). Pengaruh Tipe Kepribadian Terhadap Intensi Membeli Dengan Penyajian Model Persuasi Heuristik-Sistematik. Manasa, 1, 133143.

Tivani, D., Wibowo, T., \& Nugraheni, P. (2019). Analisis Berpikir Kritis Matematis Siswa Sma Dalam Penyelesaian Masalah Matematika. Prosiding Sednika, 5, 161-166.

Wardy, A., \& Djamil, M. (2019). Analisis Profile Kepribadian Menggunakan Disc Yang Mempengaruhi Penyelesaian Studi Mahasiswa Magister Manajemen Umb Kampus Kranggan. Indikator: Jurnal Ilmiah Manajemen \& Bisnis, 3, 78-90.

Wati, M. K., Sujadi, A. A., Studi, P., Matematika, P., Sarjanawiyata, U., Yogyakarta, T., \& Masalah, P. (2017). Analisis Kesalahan Dalam Menyelesaikan Masalah Matematika Dengan Menggunakan Langkah Polya Siswa Kelas VII SMP. Jurnal PRISMA Universitas Suryakencana, VI, 9-16.

Widodo, S. A. (2013). Analisis Kesalahan Dalam Pemecahan Masalah Divergensi Tipe Membuktikan Pada Mahasiswa Matematika. Jurnal Pendidikan Pengajaran, (2), 106-113.

Zhou, Q., Huang, Q., \& Tian, H. (2013). Developing Students' Critical Thinking Skills By Task-Based Learning In Chemistry Experiment Teaching. Creative Education, 4, 4045 . 